To Know One's Own: Estate Surveying and the Representation of the Land in Early Modern England

Author(s): Andrew McRae

Source: The Huntington Library Quarterly, Vol. 56, No. 4 (Autumn, 1993), pp. 333-357

Published by: University of California Press

Stable URL: http://www.jstor.org/stable/3817581

Accessed: 06/08/2009 04:53

Your use of the JSTOR archive indicates your acceptance of JSTOR's Terms and Conditions of Use, available at http://www.jstor.org/page/info/about/policies/terms.jsp. JSTOR's Terms and Conditions of Use provides, in part, that unless you have obtained prior permission, you may not download an entire issue of a journal or multiple copies of articles, and you may use content in the JSTOR archive only for your personal, non-commercial use.

Please contact the publisher regarding any further use of this work. Publisher contact information may be obtained at http://www.jstor.org/action/showPublisher?publisherCode=ucal.

Each copy of any part of a JSTOR transmission must contain the same copyright notice that appears on the screen or printed page of such transmission.

JSTOR is a not-for-profit organization founded in 1995 to build trusted digital archives for scholarship. We work with the scholarly community to preserve their work and the materials they rely upon, and to build a common research platform that promotes the discovery and use of these resources. For more information about JSTOR, please contact support@jstor.org. 


\section{To Know One's Own: Estate Surveying and the Representation of the Land in Early Modern England}

by Andrew McRae

The practice of estate surveying in early modern England has long been associated with widespread processes of change in the agrarian economy and social order. With the effects of inflation and a rising population placing increasing pressures on landholders in the sixteenth and seventeenth centuries, the practice of surveying is thought to have facilitated and promoted the socioeconomic restructuring which changed the face of rural England. Recent studies have confirmed impressions of the occupation's growing importance in this period; indeed, one modern historian dates "the birth of the modern surveyor" between 1520 and 1620, a period central in ongoing arguments over the rise of agrarian capitalism. ${ }^{1}$ Within this context, the present essay focuses on the development of a discourse associated with the practice of surveying. It argues that the innovative methods and attitudes adopted by estate surveyors in the sixteenth and seventeenth centuries challenged the ideals and models in terms of which agrarian life had traditionally been perceived. At the beginning of the period, social critics responded to the phenomenon of agrarian change by insisting upon the preservation of an immutable and patriarchal socioeconomic structure, ordered around the imperatives of a strict Christian morality. By contrast, proponents of surveying gradually forge strategies for the representation of the land and property relations which are underpinned by a radically new socioeconomic logic. As they proclaim the need for every landholder to "know one's own," the surveyors represent the land as property: to be held, developed, or transferred within a dynamic market economy. 


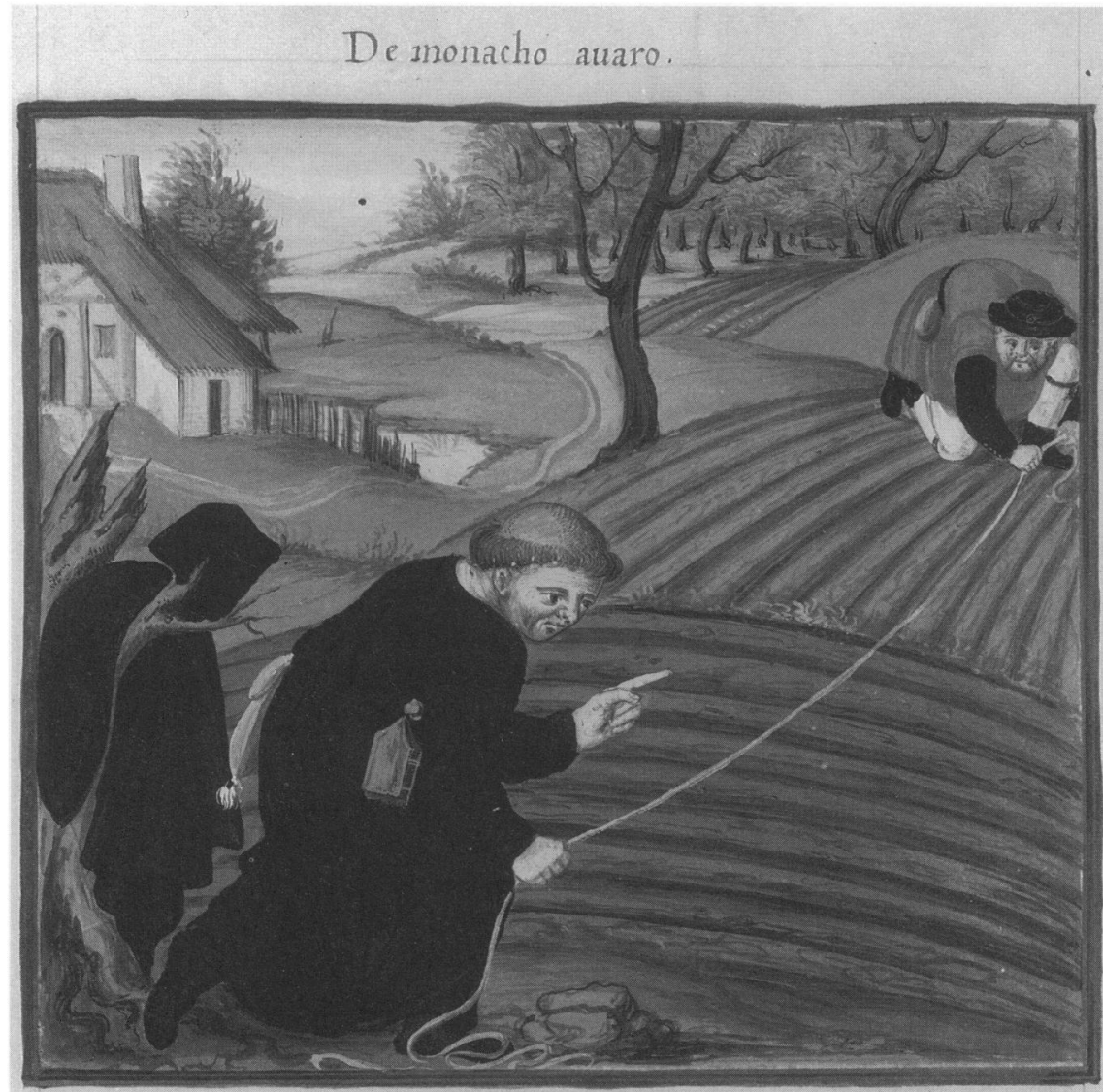

\section{Propter iniquitatem auaritix eins iratus fum, et perculli cum: abfcondi et indignatus fum: $E \mathrm{t}$ abijt vagus in via cordis fui.Efay. 57 .}

Elizabethan manuscript illustration of monks measuring land, intended to portray a link between the former monastic estates and rapacious economic practices (Huntington Library MS. HM 160, fol. 35r). The supporting quotation is Isaiah 57:17: "For the iniquity of his covetousness was I wroth, and smote him." 
The tensions raised by the new prominence of estate surveyors may be illustrated by a terse exchange that took place in the House of Commons in 1601. Parliament was debating the continuance of twin acts passed in the previous session to maintain existing levels of grain production in England and Wales. In both 1597 and 1601 these acts stimulated highly emotive debate; those supporting the legislation appealed to a model within which economic relations are based on a static moral order while those against raised a cry for economic liberty. Robert Johnson, representing Monmouth boroughs in 1601, had spoken against the acts and, presumably referring to the considerable geographical restrictions placed on the laws, made an apparently innocuous suggestion, "That the Qurestion might be, Whether it should be as well in the General Law, as the particular?" Yet the comment drew a sharp personal rebuke from the stridently conservative voice of Edward Glascock. For Johnson was a surveyor, and Glascock seized on this fact as he announced to the House: "I think the Gentleman that last spake hath better Skill in Measuring of Land, than Mens Consciences. I think it is a good Law, and fit still to stand on Foot: For if we lose Religion, Let us lose Land too." 2

Glascock drives a wedge between the moral "conscience" which he claims Parliament should reinforce within the agrarian economy and the rationalistic logic of the land-measurer. From his perspective, the estate surveyor is seen as an agent of those whose covetousness threatens the existing order: most particularly, of landlords enclosing common lands and causing the depopulation of rural villages. Indeed the surveyor appears in this light in a rich vein of conservative criticism of agrarian change, which runs throughout the early modern period. ${ }^{3}$ Writing in 1548, for example, the Protestant polemicist Robert Crowley predicts for surveyors "a plage, of al plages most horryble." He says that "God hath not sette you to surveye hys landes, but to playe the stuardes in his householde of this world, and to se that your pore below tenantes lacke not theye necessaries." 4 Crowley sets up a socioeconomic model in which possession of land is seen as constituting a position of stewardship, bringing with it social duties as well as rights and privileges. The work of the surveyor is represented as plotting the downfall of this structure, as he brings to the manor his new methods of geometrical measuring, strict legal categorizations of tenurial relationships, and mysterious tables for the determination of land values. (In the words of an early seventeenthcentury writer, the surveyor is the "Quartermaster" of enclosing landlords and "goes like a Beare with a Chaine at his side." 5 Although he was not necessarily motivated himself by covetousness, his practice is seen to facilitate the selfish desires of an emerging breed of rapacious landlords.

Crowley's attacks focus on a relatively new figure in rural England. The medieval estate survey was typically performed by a manorial offi- 
cial and involved a review of the customary "bundle of rights that made up a manor, based on the testimony of 'true and sworn men' of the district." 6 The "modern surveyor," however, was increasingly seen as an independent specialist who brought to an estate a newly legalistic appreciation of tenurial relationships and newly rationalistic standards of land measurement and estate planning. The contemporary awareness of this development is reflected in the use of the word surveyor itself, which suggests the emergence of more specialized concepts of the profession from around the middle of the sixteenth century. While the word had been in use since the Middle Ages, it had generally been applied to government officials, such as the Surveyor of the King's Works. ${ }^{7}$ Indeed the activities of "surveyors" employed in every county by Elizabeth I are best understood in this light, and Jacobean arguments about the role of surveyors on Crown lands focused on the very definition of the role and duty of the office as traditionally defined. 8 The new surveyors, who would propel the debate about Crown lands, had gradually risen to prominence over the preceding decades. The Oxford English Dictionary dates at 1551 the first use of the word to mean, "One whose business it is to survey land ... ; one who makes surveys, or practises surveying." 9 Similarly, the first recorded use of the transitive verb with the meaning, "To determine the form, extent, and situation of the parts of (a tract of ground, or any portion of the earth's surface) by linear and angular measurements, so as to construct a map, plan, or detailed description of it," dates from 1550; the $O E D^{\prime}$ s source here is another attack on surveyors, by Crowley. 10

Within this developing yet contentious field of activity, a number of practicing surveyors published manuals to explain and justify their work. ${ }^{11}$ These texts undoubtedly present an overdrawn image of a disorganized field, littered with poorly trained and part-time practitioners; however, their descriptions and arguments, intended both to educate fellow practitioners and reshape the public perception of surveying, document the gradual definition of a set of professional ideals and objectives. Several of the manuals employ the structure of a dialogue, in which a surveyor convinces skeptical tenants and farmers of the value of his craft. Edward Worsop's A Discoverie of sundrie errours and faults daily committed by Landemeaters admits from the outset the unreliability of contemporary standards but aims to "manifest these enormities popularly" and to justify true surveying to the "common sorte."12 Worsop's didactic use of a dialogue form is followed, in the early seventeenth century, in both John Norden's Surveiors Dialogue ${ }^{13}$ and R. Churche's An olde thrift newly revived. ${ }^{14}$ Other texts which demand consideration range from theoretical geometrical works, including Robert Recorde's The Pathway to Knowledge ${ }^{15}$ and Leonard Digges's highly successful A Boke Named 
Tectonicon, 16 to more practical manuals for the practicing surveyor, such as Valentine Leigh's The Most Profitable and commendable science, of Surveying, ${ }^{17}$ and Aaron Rathborne's The Surveyor in Foure Bookes. ${ }^{18}$ In all, some twenty separate texts which deal with the practice and theory of surveying survive from the years 1520 to 1650, while extant manuscripts of the writings of prominent surveyors provide an additional source.

This essay traces the emergence in these works of a distinctly new vision of agrarian order. As demonstrated by the attack on Johnson in the Commons at the turn of the century, surveyors faced personal and ideological criticism throughout the period, and the discourse of the modern surveyor emerges only gradually, laced with defensive concessions to traditional ideals. Indeed it is not until the middle of the seventeenth century that a surveying manual-William Leybourn's The Compleat Surveyor-is published without any extended argument in support of the practice. ${ }^{19}$ Through the theoretical uncertainties and moral anxieties which characterize the texts, I will argue, the surveyors grapple their way toward a vision of rural life which would underpin the emergent capitalist society of early modern England.

The following section will consider the rise of the surveyor within the social, economic, and intellectual context of the period, and will address the ways in which some among this new professional group attempted to justify their activities in the face of conservative criticism. The subsequent section will concentrate more specifically on descriptions of technical advances in land measurement and estate mapping. The surveyors' promotion of these innovative practices, it will be argued, stimulates the most coherent and forthright representations of a world in which every landholder may truly "know one's own."

\section{"Perfect Knowledge" and "Prudent Improvement":}

The Emerging Ideals of the Surveyor

The earliest printed English surveying manual is John Fitzherbert's The Boke of Surveying and Improvements. ${ }^{20}$ First published in 1523, this work presents a view of surveying which in many respects prefigures the development of the field over the following century. Fitzherbert's representation of the surveyor is in alignment with the established role of an estate steward, as he explains, "The name of a surveyour is a frenche name / and is as moche to say in Englysshe as an overseer" (fol. 34r). His description of a surveyor's duties revolves around the administration of the court of survey, at which he was expected to examine records of tenure and receive tenants for their performance of homage and fealty. As prescribed by Fitzherbert, in the ceremony of homage the tenant 


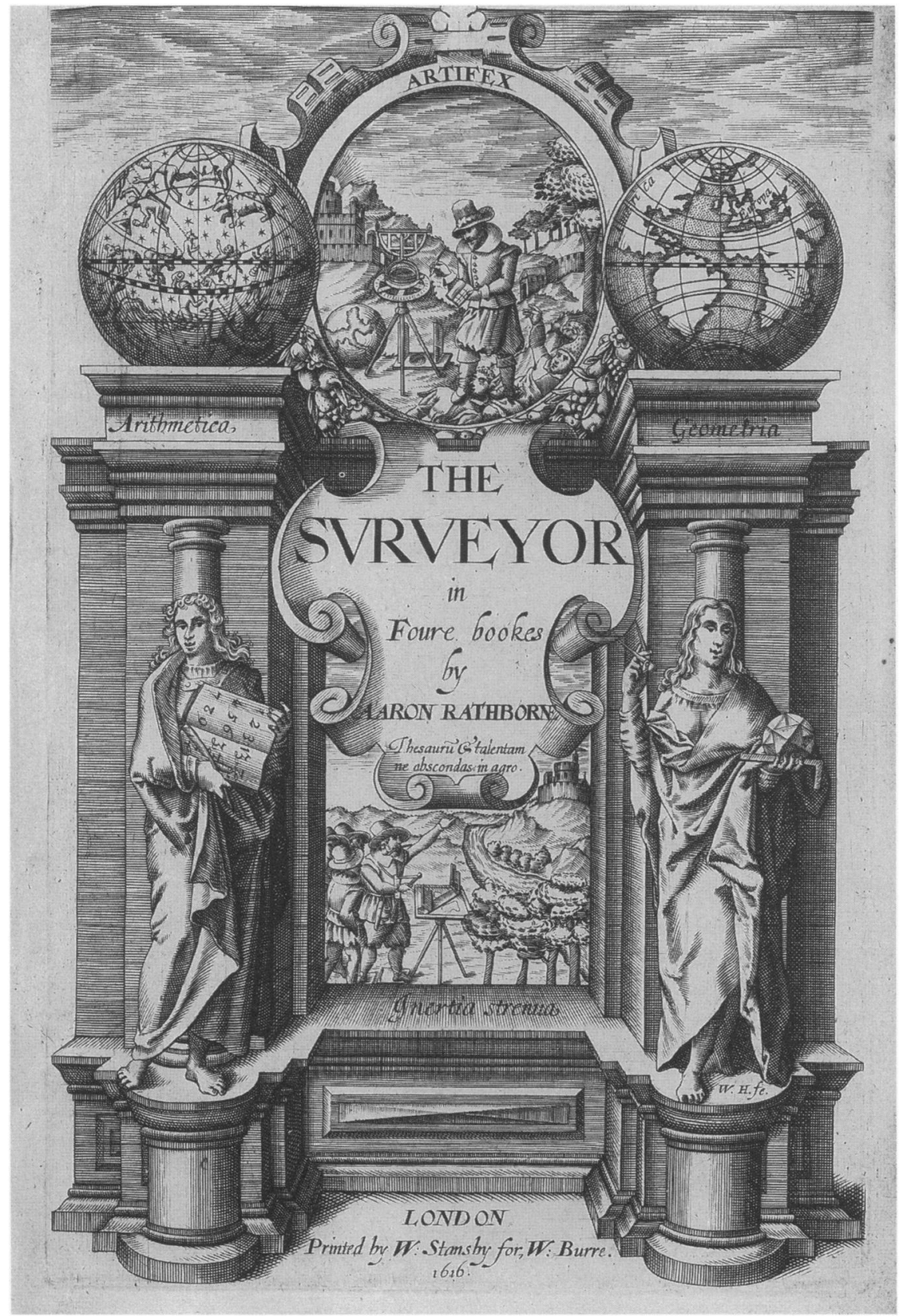

Title page of Aaron Rathborne, The Surveyor in Foure bookes (1616), with inset ilustrations of a surveyor at work in the fields (Huntington Library, RB 21775). 


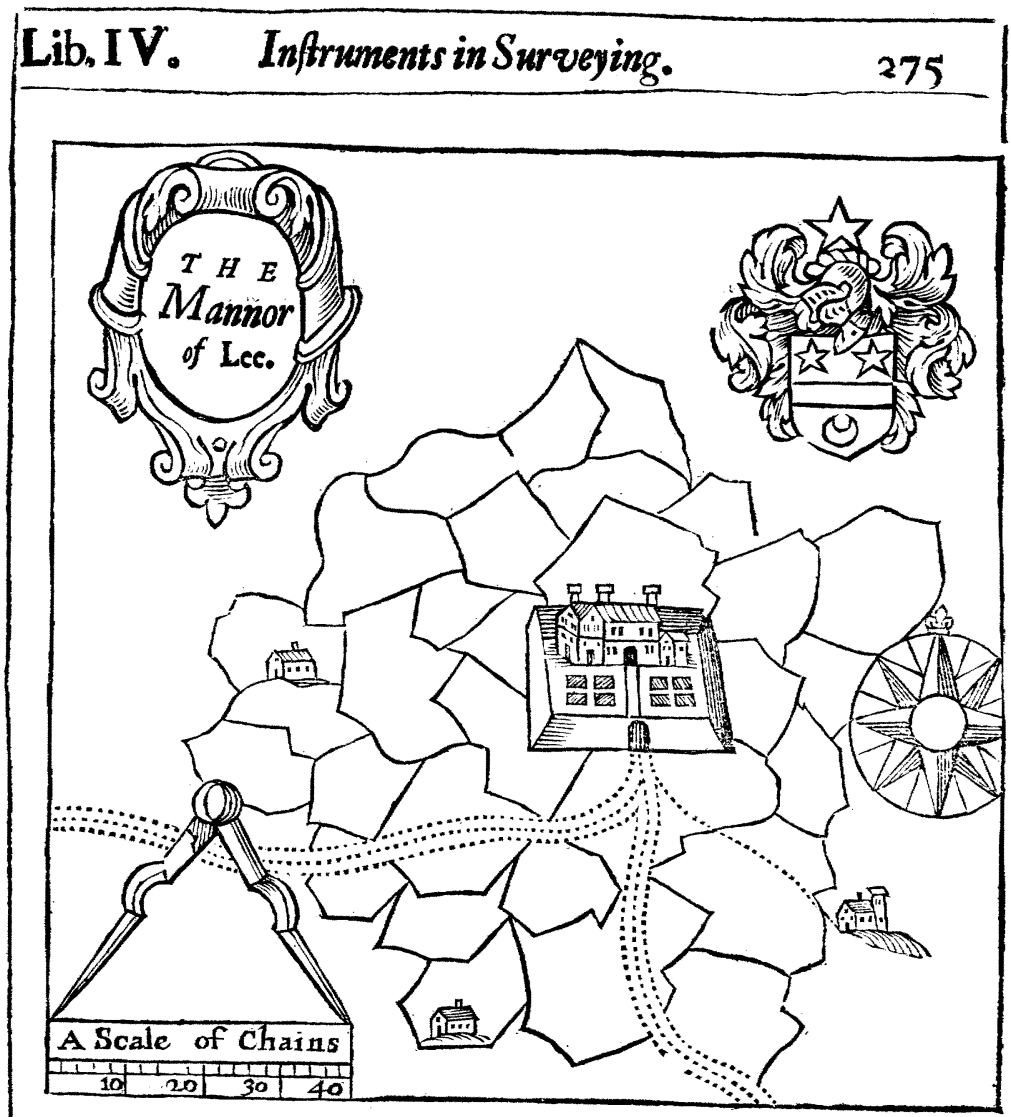

Thefe things being well performed, your plot will be a neat Ornament for the Lord of the Mannor to hang in his Study, or other private place, fo that at pleafure he may fee his Land before him, and the quantity of all or every parcell thereof without any further
trouble.

Alfo in your plot muft be expreffed the Mannor-houfe according to its fymetry or fituation, with all other houfes of note, alfo all Water-mils, Wind-mils, and whatfoever clfe is neceffary, that may
be put into your Plot without confufion.

For farther explanation of what hath been delivered in this Chapter, I have here added the figure of a fmall Mannor, which will be fufficient for example fake.

\section{$\mathrm{Nn}_{2}$ \\ Cha p.}

A model estate map published in William Leybourn, The Compleat Surveyor (1653; Huntington Library, RB 318803). 
shalbe ungirde and his heed uncovered and the lorde shall syt \& the tenaunt shall knele before hym on bothe his knees and shall holde his handes stretched out togyder bytwene the lordes handes and shall saye thus. I become your man from this day forwarde of lyfe and or membre and of worldely honour. And to you shall be faythfull and lowly and shall beare faythe to you for the landes and tenementes the which I holde of you. (Fol. 31v)21

Whatever the economic basis of the relationship between landlord and tenant, this ritualized representation clearly stresses personal bonds. The court of survey, Fitzherbert suggests, simply reinforces traditional assumptions of a patriarchal socioeconomic hierarchy within the manor.

From this conservative base, however, The Boke of Surveying documents the tentative development of a distinctly new discourse of surveying. Fitzherbert declares his desire that the landlord should have a "parfyte knowledge" of his lands and tenants (sig. b2r), an ideal increasingly linked, from Fitzherbert on, with new standards of information regarding the size and legal basis of landholdings. Moreover, this knowledge is clearly structured around an economic appreciation of the land; "in myne opinyon," he writes, the "honour and degre [of landowners] is upholden and maynteyned by reason of theyr rentes issues revenewes and profytes" (sig. b2r). Subsequently, as signaled in the full title of the book, this rationalistic perception incorporates a concern for the "improvement" of rents, issues, revenues, and profits. The language of agrarian "improvement," as I have shown elsewhere, emerges in the course of the sixteenth and seventeenth centuries as an important means for the justification and promotion of both individual economic aspirations and large-scale commercial development. ${ }^{22}$ Fitzherbert's Surveying marks an early stage in this process. In particular, the text includes possibly the earliest published argument in favor of the enclosure of common lands, in a chapter headed "Howe to make a townshippe that is worthe twentie marke a yere worthe .xx. li. a yere" (fols. 53v-56r). ${ }^{23}$ His justification of this process strikes a telling note of economic individualism, as he claims that the "tenauntes shulde exchaunge their landes with one another . . . for doute them nat but they knowe it beste, and every tenaunt for his owne advauntage wyll do it indifferently" (fol. 55v).

By 1567, when The Boke of Surveying was published for the last time, its lessons and ideals had largely been superseded by rapid changes in the theory and practice of surveying. These developments were principally propelled by economic forces which, regardless of their nature, created a demand for improved standards in the apportionment of property rights. Inflation and a rising population increased the pressure on the available land, while on the other hand the dissolution of the monaster- 
ies stimulated the private property market by releasing hundreds of estates from the hands of the Church. ${ }^{24}$ In a parallel movement, the rational standards of a national legal system were more widely applied throughout the countryside. The power of the manorial courts was being eroded, as property disputes were increasingly drawn beyond the microcosm of the manor, for determination by the courts in London. Moreover, the stewards or "overseers" described by Fitzherbert were frequently replaced by men such as common law attorneys or barristers of the inns of court. ${ }^{25}$ Throughout this movement the predominant trend was toward a solidification of "the fluid customary claims of landlord and tenant into rights which could be maintained at common law." 26 But solidifying some structures undermined others; "property," as E. P. Thompson claims, was being "loosed for the market from its uses and from its social situation." 27

The surveying texts published from the middle of the sixteenth century increasingly present a new image of the surveyor and his craft, in line with these patterns of change in the countryside. Fitzherbert's permanent "overseer" is thus refashioned as a more specialized temporary employee who brings to an estate new standards of knowledge and order. The dialogues, in particular, promote this new image as they describe the surveyor visiting an estate and giving advice to its various occupants. Norden's Surveiors Dialogue, for instance, begins with a discussion between the surveyor and a tenant, in which the former convinces his initially hostile companion about the importance of his craft; then the surveyor discusses with the lord the constitution of a manor and the treatment of tenants; then he conducts a court of survey; and in books 4 and 5 he discusses land measurement and improved methods of husbandry with the tenant, now acting as a bailiff. For the 1610 edition a sixth book on the purchasing of land was added, further tying the work to the pressing realities of a dynamic land market.

Radulph Agas, a surveyor active in the later decades of the sixteenth century, endorses this new image through a campaign of self-promotion. In two publications and several letters sent to Burghley and other state officials, Agas consistently emphasizes the value of his specialized knowledge and experience. One of his printed texts is a single-sheet advertisement, the only survivor of perhaps dozens of such documents published by practicing surveyors, which are said in one dialogue to have been found "fixed upon posts in the streetes" of London. ${ }^{28}$ This statement focuses throughout on the definition and status of the occupation, beginning with the declaration that

No man may arrogate to himself the name and title of a perfect and absolute Surveior . . . unlesse he be able in true forme, measure, 
quantitie, and proportion, to plat the same in their particulars, ad infinitum, and thereupon to retrive, and beat out all decaied, concealed, and hidden parcels thereof. ${ }^{29}$

Agas advertises the value to the landowner of the technical skills and strict objective standards of the "perfect and absolute Surveior." He emphasizes the "retrieval" and definition of information, which is figured in the rational terms of "forme, measure, quantitie, and proportion." The potential employee thus proclaims his ability to define the "true" structure of an estate, a definition with social as well as economic consequences.

The ideals of "perfect knowledge," however, required considerable justification in the face of conservative criticism. Norden, writing almost ninety years after Fitzherbert, presents in his Surveiors Dialogue one of the most extensive defenses of the occupation. Norden's figure of a discontented tenant farmer begins by attacking the surveyor. He charges, "you looke into the values of mens Lands, whereby the Lords of Mannors doe racke their Tennants to a higher rent and rate then ever before"; and "by your meanes rents are raysed, and Lands knowne to the uttermost Acre." In his defense, the Surveyor replies,

I perceive that the force of your strongest arguments is . . . your feare and unwillingnesse that the Lord of the Mannor, under whom, \& in whose Land you dwell, should know his owne: and that you thinke it better for you, that he should continue still ignorant of what he hath, and that your estates should bee alwaies hidden. (Pp. 3-4)

The argument turns on the verb "to know." The farmer is worried about the consequences of land being "knowne to the uttermost Acre," while the surveyor argues that the landlord has a right to "know his owne." The latter phrase, which recurs throughout the surveying manuals, epitomizes contemporary justifications of the practice. It assumes a social and economic order in which rights to the land can clearly and objectively be determined, in a manner which precludes competing or loosely defined customary claims. Landownership is thus figured as reducible to facts and figures, a conception which inevitably undermines the matrix of duties and responsibilities which had previously been seen to define the manorial community. In the perception of the surveyor, the land is defined as property, as the landlord's "own."

Such a fundamental shift, however, was bound to be entangled in a web of anxieties and contradictions. Indeed Norden, like almost all of the other contemporary publicists of surveying, maintains a commitment to traditional ideals. While the farmer's complaints suggest the emergence of an ideology that appreciates land as a commodity and ten- 
ants as free economic agents, the surveyor's typical defense clings to a representation of the patriarchal moral economy of the manor. In a characteristic statement, Norden says of the landlord-tenant relationship:

And therefore ought there to be such a mutuall concurrence of love and obedience in the one, and of aide and protection in the other, as no hard measure offered by the superiour, should make a just breach of the loyaltie of the inferiour: which kind of union is no wayes better preserved . . . then by the Lords true knowledge of the particulars that every Tenant holdeth, and a favourable course in fines and rents: and by the Tenants love and thankfulnesse in all readie service and dutie towards the Lord. (Sig. ${ }^{*} 2 \mathrm{v}$ )

The statement raises again the surveyor's ideal of "true knowledge," yet attempts to restrain this potentially disruptive force within the bonds of "a mutuall concurrence of love and obedience." This is a strategy which emerges as a central convention of the surveying manuals, yet it is fraught with ideological tensions. The methodical collection of "true knowledge" in an estate survey effectively objectifies traditional assumptions about socioeconomic relationships. Ideals such as "love" and "loyalty" are increasingly subordinated to rational standards of land quantification and valuation. Moreover, for all his insistence on a universal morality, the surveyor ultimately transmits his "knowledge" into the hands of his employer. And Norden is utterly conventional when he declares that while some knowledge is "publique, as the names of grounds, the owners, their estates, buts, bounds, \& such like," other information remains "private, \& to be concealed, as the quantities, and supposed yeerely values. These are for the Lord" (p. 183). Consequently the knowledge itself becomes another form of property, which serves to reinforce the landlord's economic power.

"The Worlde Was Merier, Before Measurings Were Used": The Surveyors' Promotion of Land Measurement and Estate Mapping

The reluctance of writers such as Norden to break with traditional conceptions of agrarian order highlights at once the continuing authority of conservative ideals and the radical potential of the surveyors' activities. In response to widespread public mistrust, the surveying publicists awkwardly attempt to link the emergent ideals of empirical knowledge to a preexistent ideological model of the stable and hierarchical manorial estate. The more strident reality of the surveyors' activities, meanwhile, was rapidly becoming apparent to those involved in the agrarian economy. For example Henry Percy, the ninth earl of Northumberland, 
relied heavily upon surveyors late in the sixteenth century, as he fashioned a dramatic economic recovery after a period of profligacy and decline. Indeed his modern biographer finds that Percy spent "anything between $£ 50$ and $£ 200$ a year over many years on surveying," and that the information gathered was duly used to effect an "improvement" of his income: from a low-point of around $£ 3,000$ per year to an annual average of $£ 6,650$ by the turn of the century. ${ }^{30}$ Similarly, a defender of the questionable reputation of Thomas Sutton (1532-1611), a wealthy trader and coal magnate, mentions his subject's "insight in surveys," and comments: "seldome shall you see a great estate got by one that is not an exact accountant and a judicious Surveyor." 31 The writer's tacit approval of an active pursuit of wealth-epitomized in his use of the verb "to get"-underlines the almost inevitable bond between surveying and individual economic aspirations within a dynamic socioeconomic structure. The judicious survey becomes an accepted tool for those aspiring to a "great estate."

Although the publicists lace their works with concessions to traditional moral standards, the manuals may nonetheless be seen to forge an independent set of professional ideals. This process may be observed most notably in arguments surrounding the technological innovations of geometrical land measurement and estate mapping. These two practices -which together distinguish the "modern" surveyor from his predecessors-prompt the writers to present distinctly new representations of the land and property relations in the countryside. Here the surveyors move toward an acceptance-and even an endorsement-of economic competition and individual improvement in a developing market economy. This section of the essay aims to identify elements of a coherent and radical discourse of surveying, which both accepts and promotes the changing role of the occupation.

Scarcity of land and an accompanying desire for greater knowledge of existing resources led to an increased use of technical methods of land measurement. Although these techniques would rapidly develop into the primary function of the modern surveyor, in the early sixteenth century measurement was a minor role approached in a fairly casual manner. Fitzherbert appears to envisage only the traditional method, whereby men would "extend and tread out" the open fields. ${ }^{32}$ This practice finds a parallel in the Rogation ceremonies, or beating the bounds, a procession originally conceived in Catholic ritual for the purpose of blessing the fields but ultimately embraced by the Elizabethan establishment, largely for its practical purpose of confirming property and parish boundaries. ${ }^{33}$ In accordance with the rationale of the medieval estate survey, these practices were intended to draw upon a collective memory of landholdings and local customs. The stable community of the manor would be reaffirmed through the regular ritual of definition. 
Yet the shortcomings of such a process for one seeking "true knowledge," either for "improving" a manor or for land transactions, are obvious. To pursue one example, around 1572 Nathaniel Bacon wrote from Norfolk to his father, the Lord Keeper Sir Nicholas Bacon, in exasperation after his inspection of the manor of Netherall:

I spent a hole daie \& half in treadinge out the ground therof by the drag of Styfkey, \& yet this notwithstandinge, I dout I have done litle good therin, for I found the drag unperfect in many places, yea so unperfect in one place as we all geassed some leafe of the boke to be lost, \& than was I forced to writ as the tenantes willed me.

The Bacons, who took a meticulous interest in the management of their estates and consistently attempted to expand their fortunes through participation in the land market, would hardly be satisfied by the traditional affirmation of an existing order. Indeed Nathaniel's concern at being "forced to writ as the tenantes willed me" evidences a governing intention to protect an individual or family interest in the face of competing claims. Later in the letter he argues the need for further investigation and estimates that it would take a month to compile a "perfect boke" of the property: a task for which he has already found "two men . . . very able to direct one." 34

The two men who offered their services to the Bacons are unlikely to have adhered to any particularly rigorous standards in their land measurement. Indeed traditional methods and inconsistent results clearly remained a problem throughout the country, well into the seventeenth century. ${ }^{35}$ Elsewhere in the Bacon correspondence, for example, the Lord Keeper writes in frustration that, "It is very straunge to me that Boldero shoulde measure the Close called Pastur Close but for 33 acres where by Hunte's measure it is 57 acres." 36 Within this context, the surveying manuals argue the necessity of standards that would be both accurate and nationally consistent. The earliest work to concentrate on measurement is Sir Richard Benese's This boke sheweth the maner of measurynge of all maner of lande, published around 1537. ${ }^{37}$ Robert Recorde's Pathway to Knowledge, however, is the first text to argue for the applicability to surveying of contemporary advances in geometry, and his work thus marks a vital break with traditional methods of quantification. Recorde launches the Pathway with a prefatory verse, spoken by Geometry:

Survayers have cause to make muche of me. And so have all Lordes, that landes do possesse:

But Tennauntes I feare will like me the lesse.

Yet do I not wrong but measure all truely,

And yelde the full right to everye man justely 


\section{Proportion Geometricall hath no man opprest, Yf anye bee wronged, I wishe it redrest.}

(Sig. $2 \pi 1 v)$

The juxtaposition of "opprest" and "redrest" in the final couplet encapsulates Recorde's central defense of geometrical measurements against the fears of conservative critics. Rather than serving the interests of the "oppressor," geometry determines and reinforces a preexistent order in the distribution of land, Recorde insists, an order which actually may have been distorted through customary practice. It yields "the full right to everye man justely," and if the tenants are unenthusiastic about the new standards, he suggests, it may well be because they have something to hide from the rightful "possessors."

Between the date of Recorde's publication and the turn of the century, interest in geometry expanded rapidly. Leonard Digges's Boke Named Tectonicon, "briefly shewynge the exacte measurynge, and speady reckenynge all maner Lande, squared Tymber, Stone, Steaples, Pyllers, Globes. \&c.," led the market, going through eight editions from 1556 to 1599, with further reprints stretching well into the seventeenth century. Another important text was Euclid's Elements of Geometry, which was published in an English translation of 1570. In a lengthy preface to this work, John Dee draws attention to the etymological connection between "geometry" and "land-measuring" and praises "[t]he perfect Science of Lines, Plaines, and Solides [which] (like a divine Justicier,) gave unto every man, his owne" (sig. a2r-v). Even in more theoretical geometrical works, the distribution of land is frequently employed as a ready example through which to illustrate points. Thus Arthur Hopton writes in 1611: "as lines bound figures, so hedges bound inclosures: and angles in the field are created by the meting of hedges, as they be in figures by the section of lines." 38 The precise, objective measurements afforded by geometry, therefore, further a fundamental shift in the perception of "one's own" as "the concept of landed property as a bundle of assorted rights over different bits of territory gave way to the idea that property lay in definable pieces of soil." 39

This development in the representation of the land is reinforced by the manuals' stress on the statute acre as a standard unit of measure. Traditionally, land was divided into units such as dayworks, ploughlands, hides, and knights' fees. These measures were derived from traditional agricultural practices within a region. A hide, for instance, is defined by William Folkingham in his Feudigraphia as a portion "as may be tilled with one teame . . . in a yeere and a day," and a knight's fee as "so much Inheritance as is sufficient yearely for the maintenance of a Knight." 40 The concept of an acre had evolved similarly. The OED notes that the original 
meaning of the term was "'open country, untenanted land, forest' . . . then, with advance in the agricultural state, pasture land, tilled land, an enclosed or defined piece of land, a piece of land of definite size, a land measure." Even in the latter sense, the dimensions of the acre originally had a customary quality, derived from the quantity of land a yoke of oxen could plough in a day; while the statutory definition, which dates from the thirteenth century, was based on the standard common-field rectangular plot of four by forty perches, or rods. ${ }^{41}$ Moreover the length of the perch, though fixed by law at 16.5 feet, might vary according to the value and use of the land. Measures could be anywhere between twelve and twenty-four feet, and local definitions could be as idiosyncratic as the one used in Buckfastleigh, Devon, during the Crown surveys of the early seventeenth century: "sixteen foot and half one inch and one barley corn square." 42

The prevalence of such local customs in the quantification of land undoubtedly helped to perpetuate traditional conceptions of socioeconomic order and agricultural practice. Units such as ploughlands and dayworks could standardize appreciations of rates of labor and sizes of landholdings within a community and constitute a significant perceptual obstacle to the potential "improver." Rathborne confirms the importance of such perceptions when he writes that the surveyor may often have to resort to questioning a tenant about his lands, "as he esteemeth them." Thus, he continues, "if he know not what acres they containe (as most tenants will seeme ignorant thereof) let him expresse of his Meadow how many daies mowing, of his Arable how many daies plowing, and of his Pasture how many Beast-gates, and the like" (p. 211). In place of this preexistent language of representation, the surveyor imposes a new logic upon the land. While the traditional units incorporated considerations of the quality and agricultural use of the land, the surveying manuals' regular insistence on the statute acre enforces an objective national standard of quantification. Cyprian Lucar, in his Treatise Named Lucarsolace, of 1590 , is representative of the publicists in his provision of instructions for the conversion of acres measured by customary units to the statutory standard. He follows an astonishingly simplistic economic logic in his argument in favor of the latter, as he compares the statute acre firstly with one measured by a twelve-foot perch, "wherewith medow grounds in diverse places of England are measured to the intollerable losses of buyers," and secondly with one measured with an eighteen, twenty, or twenty-four-foot perch, "which are also used in many places of this realme by measurers of wood lands to the manifold disadvantages of sellers" (p. 9). From the rationalistic perspective of the land-measurer, any diversions from the statutory standard become abnormalities which endanger the economic order of the property market. 
The manuals also promote the awareness of area measured in square units. Traditional representational measures, it has been demonstrated, take very little consideration of square dimensions. ${ }^{43}$ The acre, therefore, was conventionally defined by its standard length and breadth as a rectangular block; and the surveyor's task was perceived to be based upon linear measurement of the land. As late as 1613 Arthur Standish reminds readers of his forestry tract New Directions of Experience that "it is to be understood, that a statute acre doth containe in length two hundred and twenty yards, and in breadth, two and twenty." 44 The influence of geometry prompts a perceptual leap. Edward Worsop, for example, in his Discoverie of sundrie errours and faults daily committed by Landemeaters, reinterprets the statutory definition of an acre when he determines that "The words, and meaning . . . of the statute certainely is: that in what fashion soever grounds do ly, that just viii. score square perches must alwaies make the acre" (sig. H4r) ${ }^{45}$ Consequently, as the manuals repeatedly emphasize, an acre need not conform to the traditional conception of a rectangular block; it can also be measured over hills and through valleys, in circles and along meandering rivers. Although the practical application of these lessons may have been obvious in parts of the country for many years, the rationalistic techniques and terminology of the surveyors profoundly altered the accepted representation of the conventional unit for quantifying land. Through the imposition of a national empirical standard, acceptance of local particularity gave way to a representation of land which would facilitate valuations and sales within a market economy.

Not surprisingly, the new spatial rationality in land quantification became one of the most contentious aspects of the modern surveyors' activities. Indeed cross-cultural studies have found a "distrust of counting and measuring" to be "typical of a great many agricultural societies." In Poland in the eighteenth and nineteenth centuries, when new standards of measurement were being enforced, "the peasants would often invoke the devil to lay his talons on the land surveyors." 46 One of the earliest of the surveying publicists to confront these traditional fears is Worsop, whose Discoverie of sundrie errours presents a particularly detailed argument in support of the new standards. Within the dialogue form, the skeptical clothier claims that "[t]he worlde was merier, before measurings were used then it hath beene since. A tenant in these daies must pay for every foote, which is an extreme matter" (sig. I2v). The statement evokes an image of a world without change, in which landlords and tenants were bound in stable and mutually satisfying relationships within territorial boundaries acknowledged throughout the community. A surveyor's quantifications upset the very basis of these relationships, and his empirical knowledge is represented as essentially sub- 
versive within the traditional model. Worsop, speaking as the undisguised didactic voice in his dialogue, replies,

Most tenants that take land after the common measurings pay for more then they should. Therefore if the tenant had true measure, he might live meryer then he doeth. Seeing most Landlords covet to let their grounds to the uttermost, and most tenants seeke to sell their wares at the hyest prices: it is verie requisite for both sides, that the land be truely measured. True measure is not extremitie, but good justice. (Sig. I2v)

Worsop counters his opponent's yearning for a fuzzy ideal of agrarian "merriness" with an argument for an objective standard of "justice" that will enable the individual tenant to "live meryer than he doeth." In attempting to counter the traditional complaint, Worsop is thus forced beyond the conservative model toward a socioeconomic discourse based on individual aspirations. The defender of land-measurement represents the land as a site of economic negotiation and dispute, and while his critic attacks the very ideology of individualism, Worsop can merely defend the accurate regulation of such a model.

Other writers focus more directly on the importance of accurate measurements for transactions in the land market. Dee, for example, in his preface to Euclid, laments,

God knoweth . . . how great wrong and injurie hath (in my time) bene committed by untrue measuring and surveying of Land or Woods, any way. And, this I am sure: that the Value of the difference, betwene the truth and such Surveyes, would have bene hable to have found (for ever) in eche of our two Universities, an excellent Mathematicall Reader. (Sigs. a3v-a4r)

Dee stresses the quality of absolute "truth" that accurate surveying brings to the quantification of the land and places this argument in an economic context through his description of the "great wrong and injurie" caused by "untrue measuring." His underlying assumption that surveying is principally of use for land transactions is reinforced in the final suggestive link between lost revenue (presumably that sustained by the Crown in its sales) and the corrective value of geometrical standards. ${ }^{47}$ The "true" survey is thus linked to the academic program of the "excellent Mathematicall Reader."

The increasing concern with the use of surveying in land sales evidences a decisive shift away from the ideals of Fitzherbert. In contrast to the medieval ideal of ordering the manor, the seventeenth-century surveyor was at least as concerned, in his representation of the land, with 
ordering the market. Folkingham presents one of the more unapologetic justifications of this development by comparing land transactions with the grain market. Focusing on the benefits to lessees of "true surveys" he writes:

It is a World to see the sottish pressures urged against the admeasuring of land, yet the Use of Ponderous and Concave Measures . . . are no lesse commendable than Common in venting of Wares and Merchandize, and what greater iniquity in the using admeasurements in Grounds than in Graine? . . . Take away Number, Weight, Measure, you exile Justice, and reduce and haile-up from Hell the olde and odious Chaos of Confusion. (Sig. A3r)

The market analogy liberates possessors of the land from the weight of the traditional emphasis on their moral responsibility for the society and economy of their estate. In contrast to Crowley's exhortation that landowners should "playe the stuardes in [God's] householde of this world," Folkingham represents the ownership and trade in land as comparable to the "venting of Wares and Merchandize." In a socioeconomic model which assumes that individuals will naturally seek their own advantage in competition with their neighbors, the only alternative to the order of the surveyor is "the olde and odious Chaos of Confusion."

The estate map was a relatively late development in the practice of the modern surveyor. ${ }^{48}$ P. D. A. Harvey claims in a recent study that "it seems to have been only in the 1580s that it started to be generally understood that an estate survey might involve making maps." 49 As was observed above in relation to changes in land measurement, the emergence of mapping was stimulated by advances in geometry and the production of new instruments for the surveyor. ${ }^{50}$ Further, the practical application of estate maps was promoted by the courts, which increasingly ordered their preparation for use in property disputes. On a wider scale, the rise of the estate map can be linked to an increasing consciousness of cartography among wealthier and better-educated members of society. By the 1580s a number of maps of Europe and the world were available in printed form from the Continent, while Christopher Saxton's Atlas of England and Wales of 1579 was undoubtedly popular among the very landowners who were potential employers of estate surveyors. ${ }^{51}$ As John Dee writes in his preface to Euclid: "some, to beautifie their Halls, Parlers, Chambers, Galeries, Studies, or Libraries with . . . liketh, loveth, getteth, and useth, Mappes, Chartes, \& Geographicall Globes" (sig. a4r).

In a map, the surveyor's practical description of an estate could be transformed into an object of display. Indeed the estate map became a significant status symbol that was especially popular among new land- 
owners, most notably those rising from commerce and the professions, who benefitted from inflation and the rapid turnover in the land market. 52 Mapping became the ultimate extra service offered by the surveyor, and the more elaborate productions could be finished with a colorcoded key to land use and decorated with the arms of the lord and illustrations of the manor house and agricultural activities. Lucar, for example, suggests the use of "diverse good and thinne water colours, to shew a difference in your mappe betweene meadowes, pastures, arable land, wood land, hilles, valleies, and grounds belonging to sundrie tenements and severall persons." The margins of this map, he suggests, should be used to record a vast range of additional information, from the quality of the soil to "the disposition, industrie, studies, manners, trades, occupations, honestie, humanitie, hospitalitie, apparell, and other morall vertues of the inhabitants" (p. 502). A slightly less ambitious model is offered by Leybourn (see illustration in this issue, p. 338 above).

A map of this kind, prominently displayed in the manor house, becomes a simple and celebratory representation of a landlord's position in relation to his estate. As J. B. Harley argues, an estate map

was also a seigneurial emblem, asserting the lord of the manor's legal power within the rural society. For him, the map was one badge of his local authority. Family coats of arms added within the margins were certainly for him more than mere decoration, for the right to these heraldic emblems also incorporated an individual's right, rooted in the past, to the possession of land. ${ }^{3}$

Simply, a map defines a manor as the lord's "own." The potential ramifications for the representation of manorial society are demonstrated in a map of the manor of Great Bookham, Surrey, prepared around 1614-17 by Thomas Clay, which omits the hovels of landless laborers. ${ }^{54}$ The map thus paints a pleasing veneer over evidence of the existence of poorer inhabitants of the manor, who might make embarrassing requests that the lord fulfill his traditional patriarchal role within the manor.

In Norden's Surveiors Dialogue, the farmer focuses his criticism of estate mapping on its potential for allowing the landlord to withdraw from the society of his manor. He says, "we poore Country-men doe not thinke it good to have our Lands plotted out, and me thinks indeede it is to very small purpose: for is not the field it selfe a goodly Map for the Lord to looke upon, better then a painted paper?" To which the surveyor replies:

I know your meaning in misliking plotting of your Land, and yet you utter not what you think: for a plot rightly drawne by true information, describeth so the lively image of a Mannor . . . as the Lord sitting in his chayre, may see what he hath, where and how it 
lyeth, and in whose use and occupation every particular is, upon the suddaine view. (Pp. 15-16)

A standard adage in the more conservative tradition of advice on estate management was that "the best doung for the feelde is the maisters foote." 55 This stress on active supervision reinforces representations of the manor as a patriarchal community, with the lord directly involved in both the working of his land and the lives of his tenants. Norden's surveyor, however, subtly reinterprets the nature of landownership. He has the lord removed from the life of the estate, "sitting in his chayre" (an image given in almost identical terms by both Lucar and Leybourn)56; and he replaces the constant patrol of the lord's feet with "the suddaine view" from the manor house.

The map, laid out before the landowner at a distance from the actual fields, therefore reinforces the ultimate logic of the surveyors' representations of the land: that the "owner" of any plot has complete control over it. As Standish writes in 1613, "now that mens lands, as is said (not only as common Table-talk, but elsewhere) is their owne, they may do with them what they list." 57 This attitude is further illustrated by the landowner in Churche's dialogue An olde thrift newly revived:

For my selfe being of some small revenew in land, I have two or three of my Manors surveyed, and the plots of them fairely set forth in colours upon Vellem, distinctly specifying which is meadow, pasture, arable, and woodland, with the quantitie, qualitie, and value thereof, with everie other thing there fitting to be noted, which I finde to be a great satisfaction pleasure, and ease to me, especially when I am to let any of those Farmes, or Tenements in any of the said Manors because they are farre remote from the place I dwell. (P. 47)

Churche's representation of an absentee landlord ordering his lands from afar directly contrasts with the traditional image of the patriarchal figure presiding within a network of reciprocal duties and moral responsibilities. Churche describes an economic order in which a landlord need not even physically see his land let alone "manure" it with his step. The landlord is encouraged to appreciate his land free of restrictive moral sanctions against practices such as sales, rent-raising, and enclosure. Radulph Agas, considering the finished product of a survey, proclaims,

Heere have you also every parcel ready measured, to all purposes: you may also see upon the same, how conveniently this or that ground may be layd to this or that tenement or messuage, aswel in regard of waies, water, floud, or otherwise: which is a thing much 
helping and conducing to a partition, or devision of such manner, or Lordship. 58

Agas promotes the map as a learning aid for the would-be improver. It reinforces the rational perspective insisted upon throughout the surveying manuals, as it graphically illustrates both the concept of area and the possibility of reorganizing landholdings. In Agas's vision, the landlord merely sits in his study and manipulates his property in accordance with the criterion of "how conveniently this or that ground may be layd to this or that tenement or messuage."

It has become apparent throughout this study that surveyors were formulating their professional ideals and objectives in the very period which has provided the focus for ongoing arguments over the emergence of agrarian capitalism. Consequently, while it has not been my purpose to engage directly with such debates, the findings here may be seen to provide a further dimension to existing studies of social and economic change. By developing a new discourse for the representation of the land, the surveying writers offered landholders at all levels a potentially revolutionary way of perceiving-and thus precipitating-important and widespread changes in the circumstances of rural England.

One of the most important manifestations of the gathering upheaval was the perception of property rights. G. E. Aylmer has noted that the first attempt at a legal definition of property is made in Christopher St. German's Doctor and Student, first published in Latin in the $1520 \mathrm{~s}^{59} \mathrm{St}$. German refers to "that generall lawe or generall custome of propretye wherby goods movable and unmovable be brought in to a certayne propretye / so that every man may knowe his owne thinge." 60 Although this statement predates by over one hundred years any identifiably modern legal appreciation of property, the echo of early modern surveying manuals is unmistakable. ${ }^{61}$ In both contexts, the phrase draws attention to an emergent desire to apportion objective rights of ownership over goods and land. Landlords and tenants alike were being encouraged to alter their appreciation of "one's own," as a socioeconomic outlook dominated by moral standards and interpersonal relations gave way to a discourse which facilitated economic individualism and competition.

A modern theorist of human territoriality has argued that "capitalism helps turn place into commodities." 62 In the history of economic development, he writes, "the repeated and conscious use of territory as an instrument to define, contain, and mold a fluid people and dynamic events leads to a sense of an abstract and emptiable space." Consequently, the "emptiable space" of capitalism "makes community seem to be artificial; it makes the future appear geographically as a dynamic rela- 
tionship between people on one hand and territorial molds on the other." 63 Such fundamental shifts in socioeconomic practice and ideals are of course never immediate or straightforward. This essay has focused on texts which graphically illustrate the struggle to refashion accepted representations of the land. Here a sense of the land as a commodity gradually emerges out of pages steeped in ideological tension. In a shift of discourse which is dynamically interrelated to processes of social and economic change, the surveying publicists struggle toward a conception of property consistent with the emergent capitalist ideal as defined by C. B. Macpherson: property is figured as an "absolute right," "a right to dispose of, or alienate, as well as to use; and ... a right which is not conditional on the owner's performance of any social function." 64

In the field of surveying it is fair to conclude that the ideological revolution was practically complete by the middle of the seventeenth century. A developing tradition of writing on the practice had moved through -and documented-an extended period of uncertainty and anxiety, and had arrived at a confident and coherent sense of purpose. Although the standards of practitioners undoubtedly lagged behind, the published manuals clearly demonstrate this important consolidation of a set of professional ideals. Thenceforth, representations of the land and property relations throughout England would be shaped by the rationalistic discourse forged by publicists of the sixteenth and early seventeenth centuries. "To know one's own" became the ethos of a countryside dominated by the emergent forces of capitalism.

University of Sydney

\section{N O T E S}

I am grateful for the comments and suggestions, at various stages in the development of this article, offered by the following people: Marie Axton, Sarah Bendall, Stephen Bending, Patrick Collinson, John Rathmell, and Joan Thirsk. Sybil Jack called to my attention the illustration in Huntington Library manuscript HM 160 of monks measuring land (facing p. 333 above).

1. F. M. L. Thompson, Chartered Surveyors: The Growth of a Profession (London, 1968), 7. See also A. Sarah Bendall, Maps, Land, and Society: A History, with a CartoBibliography of Cambridgeshire Estate Maps c. 1600-1836 (Cambridge, 1992); and the recent Annals of Science special issue on surveying, 48 (1991).

2. Hayward Townshend, Historical Collections: or, An exact Account of the Proceedings of the Four last Parliaments of Q. Elizabeth (1680), 291. Johnson became a leading figure in the Jacobean drive toward a thorough survey of Crown lands. His work is well documented in R. W. Hoyle, ed., The Estates of the English Crown, 1558-1640 (Cambridge, 1992).

3. I will analyze this vigorous "discourse of agrarian complaint" at length in God Speed the Plough: The Representation of Agrarian England, 1500-1660 (forthcoming, Cambridge University Press). 
4. An informacion and Peticion agaynst the oppressours of the pore Commons of this Realme (1548), sig. A7r-v.

5. Donald Lupton, London and the Countrey Carbonadoed (1632), 106.

6. Thompson, Chartered Surveyors, 3.

7. Ibid.

8. On the Elizabethan "surveyors" of Crown lands, see David Thomas, "The Elizabethan Crown Lands: Their Purposes and Problems," in Hoyle, ed., Estates of the English Crown, 66. In the same volume, Hoyle traces the Jacobean debate over surveying ("'Shearing the Hog': The Reform of the Estates,

c. 1598-1640," 212-19).

9. OED 3a; from Robert Recorde, The Pathway to Knowledge.

10. OED 2; from Crowley's A One and Thyrtye Epigrammes.

11. In order to establish a sense of the distribution and significance of individual texts during particular periods, I will cite the number of editions and their dates for each text cited, as given in the Short Title Catalogue.

12. 1582 , sig. A2v.

13. Three editions $(1607,1610,1618)$; references are to the 1610 edition, the last to contain substantive emendations.

14. 1612.

15. Three editions $(1551,1574,1602)$; references are to the first edition.

16. Seventeen editions (1556-1699); references are to the 1562 edition.

17. Five editions, 1577-96; references are to the first edition.

18. 1616.

19. 1616.

20. Four editions (1653-79).

21. Eleven editions (1523-67); references are to the first edition. There is a continuing debate over whether the book was written by John Fitzherbert or his brother Sir Anthony, the prominent legal writer. As this issue has only peripheral significance in the current study, I will accept the more traditional attribution to the former.

22. Compare the almost identical description in Sir Thomas Littleton's Tenures in Englyshe (1544 ed., fol. 19v), a possible source for Fitzherbert.

23. "Husbandry Manuals and the Language of Agrarian Improvement," in Michael Leslie and Timothy Raylor, eds., Culture and Cultivation in Early Modern England: Writing and the Land (Leicester, 1992), 35-62.

24. Also published in R. H. Tawney and Eileen Power, eds., Tudor Economic Documents, 3 vols. (London, 1924), 3:22-25. (The improvement from twenty 
marks to twenty pounds represents an increase in value of fifty percent.)

25. Joyce Youings calculates that more than three-quarters of the former monastic estates had been alienated by 1558 and stresses that the dispersal was generally administered on strictly economic grounds (The Dissolution of the Monasteries [London, 1971], 117-31).

26. C. W. Brooks, Pettyfoggers and Vipers of the Commonwealth: The "Lower Branch" of the Legal Profession in Early Modern England (Cambridge, 1986), chaps. 4-5. Mervyn James argues in relation to Durham that this development promoted "a considerable readjustment of the traditional submissive posture characteristic of most ... tenants in the early sixteenth century," and furthered a general trend whereby landlord-tenant relationships came to be seen as contractual rather than based on personal dependence (Family, Lineage, and Civil Society: A Study of Society, Politics, and Mentality in the Durham Region, 1500-1640 [Oxford, 1974], 79-83.)

27. Brooks, Pettyfoggers and Vipers, 201.

28. "The Grid of Inheritance: A Comment," in Jack Goody, Joan Thirsk, and E. P. Thompson, eds., Family and Inheritance: Rural Society in Western Europe, 1200-1800 (Cambridge, 1976), 328-60 (quotation on p. 341). See also C. B. Macpherson, "Capitalism and the Changing Concept of Property," in Eugene Kamenka and R. S. Neale, eds., Feudalism, Capitalism, and Beyond (London, 1975), 105-24, esp. 106-11.

29. Norden, Surveiors Dialogue, 14.

30. To all persons whom these presents may concerne, of what estate and degree soever (c. 1596). See also A Preparative to Plattinge of Landes and Tenements in Surveigh (1596); "Note by R.A., of what he is able to perform," Brit. Lib., Add. MS. 12497, fol. 346r; "Note of Radulph Agas touching surveyors, and against the turning of copyholds into freeholds," Brit. Lib., Add. MS. 12497, fol. 342r; “R.A. to Lord Burghley, showing his art of land measure," Brit. Lib., Lansdowne MS. 73, fol. 107r; and Brit. Lib., Lansdowne MS. 84, fol. 69r (a letter to Burghley concerning mistakes in land measuring made in the fens).

31. Gordon R. Batho, "The Finances of an Elizabethan Nobleman: Henry Percy, Ninth Earl of Northumberland (1564-1632)," Economic History Review, 2d ser., 9 (1957): 433-50 (quotation on p. 441). While the inflation of the 1590s may affect the real significance of these figures, they nonetheless demonstrate a vigorous program intended to overcome the effects of such fluctuations.

32. "How Mr. Sutton got his great estate," Brit. Lib., Lansdowne MS. 825, fol. 66. This anonymous document is undated but the hand suggests a composition anywhere between c. 1620 and c. 1750 . A relatively early date is more probable, however; there is a fragment on the recto of the sheet, written in an early to mid-seventeenth-century hand, about "The Life and Death of Bishop Ravis," a relatively obscure bishop of Oxford who died in 1609. (I am grateful to the staff of the Manuscripts Room of the British Library for assistance with this information.) 
33. See Thompson, Chartered Surveyors, 7-8.

34. Maurice Beresford, History on the Ground: Six Studies in Maps and Landscapes, rev. ed. (London, 1971), 289.

35. The Papers of Nathaniel Bacon of Stiffkey, ed. A. Hassell Smith, Gillian M. Baker, and R. W. Kenny, 2 vols. (Norwich, U.K., 1979, 1983), 1:712.

36. Bendall, Maps, Land, and Society, 78-79. Bendall discusses changing methods of land measurement, pp. 129-31.

37. Papers of Nathaniel Bacon, 1:30.

38. Five editions (1537?-c. 1565). Interestingly, Benese learned his craft as a canon of the Augustinian priory of Merton. However, the kind of antimonastic propaganda in the manuscript illustration shown in this issue of $H L Q$, opposite p. 333, which suggested that monks were especially rigorous in their surveying, does not appear to have any basis in fact.

39. Speculum Topographicum: Or The Topographicall Glasse, sig. a1v.

40. Thompson, Chartered Surveyors, 10.

41. Feudigraphia. The synopsis or epitome of surveying (1610), 60. Compare Cyprian Lucar's claim that " 8 . hides of land make a Knights fee, which . . . is a plough till a yeare" (A Treatise Named Lucarsolace [1590], 8).

42. OED 2a. See also Philip Grierson, English Linear Measures: An Essay in Origins, Stenton Lecture, 1971 (Reading, U.K., 1972), 24; and Ronald Edward Zupko, A Dictionary of English Weights and Measures: From Anglo-Saxon Times to the Nineteenth Century (Madison, Wisc., 1968), 35.

43. Quoted by Heather Lawrence, in "John Norden and his Colleagues: Surveyors of Crown Lands," The Cartographic Journal, 22 (1985): 54-56 (quotation on p. 55).

44. See Witold Kula, Measures and Men, trans. R. Szreter (Princeton, N.J., 1986), 42.

45. Fourth edition (1615), 6.

46. Compare Digges, who clearly understands the concept of land quantification by squared units but appears to lack the vocabulary with which to express it, as he declares that "an Acre by statute ought to conteine 160 pearches" (sig. B1r).

47. Kula, Measures and Men, 14, 16.

48. On the failure of the Elizabethan regime to take advantage of advances in surveying, see Thomas, "The Elizabethan Crown Lands."

49. On the development and significance of estate mapping from 1600 into the nineteenth century, see Bendall, Maps, Land, and Society.

50. "Estate Surveyors and the Spread of the Scale-Map in England, 1550-80," publication forthcoming in Landscape History. (I am grateful to Professor Harvey 
for providing me with a copy of this paper.)

51. The title page of Rathborne's The Surveyor (see this issue of HLQ, page 337) shows a surveyor at work with two such instruments: a theodolite (in the illustration above the title) and a plane table (below the title).

52. P. D. A. Harvey, "Estate Surveyors"; and see also Richard Helgerson's chapter on cartography and chorography in his Forms of Nationhood: The Elizabethan Writing of England (Chicago and London, 1992), chap. 3.

53. Alison Sarah Bendall, "The Pride of Ownership: English Estate Maps c. 1600-1840," paper delivered at the Warburg Institute, December 1991. (I am grateful to Dr. Bendall for providing me with a copy of this paper.) See also Bendall, Maps, Land, and Society, 153.

54. "Meaning and Ambiguity in Tudor Cartography," in Sarah Tyacke, ed., English Map-Making 1500-1650 (London, 1983), 24-44 (quotation on p. 37).

55. J. H. Harvey, “Thomas Clay's Plan of the Manor of Great Bookham, Surrey, 1614," Proceedings of the Leatherhead and District Local History Society 2 (1966): 281-83 (quotation on p. 282).

56. See, for example, Conrad Heresbach, Foure Bookes of Husbandry, trans. Barnabe Googe (London, 1577), fol. 3r.

57. Lucar, A Treatise, 53; Leybourn, Compleat Surveyor, 275.

58. New Directions of Experience, sig. B1v.

59. Agas, Preparative to Plattinge, 14-15.

60. "The Meaning and Definition of 'Property' in Seventeenth-Century England," Past and Present 86 (1980): 87-97 (quotation on p. 87).

61. Hereafter foloweth a Dyaloge in Englysshe / betwyxt a Doctoure of Dyvynyte / and a Student in the Lawes of Englande, 1530 English ed., sig. c2v.

62. Aylmer analyzes the development of a legal conception of property in "The Meaning and Definition of 'Property.'"

63. Robert David Sack, Human Territoriality: Its Theory and History (Cambridge, 1986), 48.

64. Ibid., 78.

65. "Capitalism and the Changing Concept of Property," 109. 